\title{
Sustainability Indicators for Community Enterprises Producing Renewable Energy in Thailand
}

\author{
Yaowanart Rungcharoennan*, Wisakha Phoochinda \\ National Institute of Development Administration (NIDA), 148 Serithai Road, Klong-Chan, Bangkapi, Bangkok 10240, \\ Thailand
}

Corresponding Author Email: yaowanartr@gmail.com

https://doi.org/10.18280/ijsdp.160512

Received: 12 November 2020

Accepted: 19 August 2021

\section{Keywords:}

community enterprise, renewable energy, sustainability

\begin{abstract}
This study aims to propose sustainability indicators for community enterprises producing renewable energy in Thailand by applying the Sustainability Balanced Scorecard (SBSC) as a conceptual framework. The literature review, a survey of the community enterprise producing renewable energy, and the assessment by eighteen experts and academics were able to summarize nineteen sustainability indicators for community enterprises producing renewable energy in Thailand which could be divided into six perspectives: (1) financial perspective of three indicators (2) stakeholder perspective of three indicators (3) internal process perspective of five indicators (4) learning and growth perspective of two indicators (5) social perspective of two indicators (6) environmental perspective of four indicators. Community enterprises producing renewable energy in Thailand can use these sustainability indicators to set their operational goals or management plans. In addition, government sector and related agencies are able to use the sustainability indicators as guidelines for the formulation of appropriate policies or measures to jointly develop and support community enterprises producing renewable energy in Thailand to self-reliance and achieve more sustainable success, affect strengthening the grassroots economy, reducing the negative social and environmental impacts of non-renewable energy production and use, increasing energy security.
\end{abstract}

\section{INTRODUCTION}

Energy is very important for human life. All economic activities, including production, consumption, and transportation, all require energy to drive. Todays, most of the energy that humans produce and use is from fossil fuels such as crude oil, natural gas and coal, which are considered nonrenewable energy. Once used, it cannot be renewed or replaced in a short time. Therefore, the energy security problem from the shortage of non-renewable resources is likely to occur in the near future. Moreover, it causes significant negative impacts on society and the environment. It contributes to global warming, toxic air, and acid rain, as the combustion of wasteful energy produces toxic gases, e.g., carbon dioxide, nitrogen oxides, sulfur dioxide, which of these gases are harmful to living organisms and can affect human health as well [1].

While, renewable energy sources are considered sustainable as they can contribute to energy needs without reducing the availability of energy sources in the future and have a low environmental impact. To encourage the use of renewable energy, raising energy self-supply by promoting the use of resources that the area possess should be an alternative. In spite of its implementation can be conditioned by the existence of the resource, costs or acceptance of the area, it is urgent that planners should include the sustainable energy use, in order to meet future shortages of resource and adverse environmental phenomenon [2].

In Thailand, The Ministry of Energy has implemented the
Local Energy Planning (LEP), which is the process of creating people's participation in efficiently energy, environment, and budget management in their own local area to enable communities to become self-reliant by endeavoring renewable energy through learning process; studying renewable energy technology; gathering and analyzing information in the community; and joint decision-making to plan their own local energy and environmental management operations. The process is considered a decentralized decision or a bottom-up energy planning based on the sufficiency and suitability of the local area, which is based on the resources available in each area [3]. The geographic features of Thailand also have facilitated a wealth of resources that can be used to produce various types of renewable energy such as biogas energy, biomass energy, solar energy, water energy, etc. Consequently, some community has formed a group to create a community enterprise producing renewable energy for self-reliance in the community, generating energy for themselves, reducing energy expenditure and environmental impacts.

However, the major problem of community enterprises in Thailand is management, i.e., a lack of knowledge of all aspects of management within the organization [4]. This problem causes many community enterprises, including community enterprises producing renewable energy, difficult to be sustainable. Although the government sector such as the Department of Agricultural Extension is responsible for supporting community enterprises under the Community Enterprise Promotion Act, only the government sector cannot be able to develop the potential of all community enterprises 
successfully. Self-assessment can be an important tool that will help the government to develop community enterprises for sustainable growth. At present, there is no specific sustainability assessment tool for community enterprises producing renewable energy in Thailand. To fill this gap, the objective of this study, therefore, is to propose sustainability indicators for community enterprises producing renewable energy in Thailand as a self-assessment tool, which is useful for community enterprises producing renewable energy in Thailand. This also enhances the ability to set operational goals and create management plans for sustainability. In addition, the government and related agencies can use it as a guideline in formulating policies or measures to be appropriate and consistent to jointly develop and support community enterprises producing renewable energy for sustainable growth with self-sufficiency.

\section{LITERATURE REVIEW}

\subsection{Sustainability Balanced Scorecard (SBSC)}

The Sustainability Balanced Scorecard (SBSC) is based on the Balanced Scorecard (BSC), a set of measures that gives a fast but comprehensive view of the business. The Balanced Scorecard (BSC), which was originally developed by Kaplan and Norton, looks at the organization from four perspectives: financial, customer, internal business, and innovation and learning [5]. To deal with sustainability issues, the Sustainability Balanced Scorecard (SBSC) has been developed. Sustainability management with the Balanced Scorecard (BSC) helps to overcome the shortcomings of conventional approaches to environmental and social management systems by integrating the three pillars of sustainability into a single and overarching strategic management tool. There are basically three possibilities to integrate environmental and social aspects in the Balanced Scorecard (BSC). First, environmental and social aspects can be integrated in the existing four standard perspectives. Second, an additional perspective can be added to take environmental and social aspects into account. Third, a specific environmental and social scorecard can be formulated [6]. The Sustainability Balanced Scorecard (SBSC) framework could be a powerful tool to facilitate assessment of the implemented sustainability strategies [7]. The Sustainability Balanced Scorecard (SBSC) is a comprehensive assessment tool in order to help enterprises measure the economic, environmental, and social performance [8]. Therefore, The Sustainability Balanced Scorecard (SBSC) is the most appropriate tool for using as the conceptual framework in this study and the design of the particular environmental and social scorecards is the most suitable as it can best reveal the condition and emphasize the significance of ecological and social accountability of the community enterprises producing renewable energy.

\subsection{Sustainable Development Goals (SDGs)}

The Sustainable Development Goals (SDGs) are a collection of seventeen interlinked global goals designed to be a "blueprint to achieve a better and more sustainable future for all". The Sustainable Development Goals (SDGs) were set up in 2015 by the United Nations General Assembly and are intended to be achieved by the year 2030. The seventeen
Sustainable Development Goals (SDGs) are: (1) no poverty (2) zero hunger (3) good health and well-being (4) quality education (5) gender equality (6) clean water and sanitation (7) affordable and clean energy (8) decent work and economic growth (9) industry, innovation and infrastructure (10) reducing inequality (11) sustainable cities and communities (12) responsible consumption and production (13) climate action (14) life below water (15) life on land, (16) peace, justice, and strong institutions (17) partnerships for the goals [9]. Fulfilling these ambitions will take an unprecedented effort by all sectors in society and business has to play a very important role in the process. No matter how large or small, and regardless of their industry, all companies can contribute to the Sustainable Development Goals (SDGs) starting by acting responsibly, operating in ways that, at a minimum, meet fundamental responsibilities in the areas of human rights, labor, environment and anti-corruption, incorporating the "Ten Principles of the United Nations Global Compact" widely into strategies and operations, and understanding that good practices or innovation in one area cannot make up for doing harm in another [10]. The social enterprises around the world are also contributing towards the achievement of the Sustainable Development Goals (SDGs). Social enterprises that contribute to the achievement of the Sustainable Development Goals (SDGs) also create significant social value in areas other than those recognized in the Sustainable Development Goals (SDGs) [11]. The Sustainable Development Goals (SDGs) should, therefore, be adopted to the sustainability indicators for the community enterprises producing renewable energy in Thailand.

\subsection{Sufficiency Economy Philosophy (SEP)}

From a growth-driven to a sustainable development policy, countries still face clear and present challenges in development. Those challenges stem from dysfunctional institutions, poor quality of people's lives, environmental degradation, and the optimal role of government. The philosophy of sufficiency economy conveys a new paradigm for development highlights a balanced way of living. Three principles of moderation, reasonableness, and self-immunity along with the two conditions of knowledge and morality, this philosophy helps address those development challenges. It can be applied to any level of the society from an individual to a country [12]. The outstanding results of small and mediumsized enterprises (SMEs) after running the business regarding to the Sufficiency Economy Philosophy (SEP) were composed of adapt to change, the innovation on product development by research and developing indigenous wisdom from generation to generation, and the ethics in business such as honesty and ability to maintain quality of product with proper capital cost [13]. To be sustainable, the community enterprises producing renewable energy, therefore, should apply the Sufficiency Economy Philosophy (SEP) as well.

\subsection{Good governance}

Good governance has eight major characteristics: participatory, consensus oriented, accountable, transparent, responsive, effective and efficient, equitable and inclusive, and follows the rule of law [14]. Nowadays, sustainable development is globally a major concern, good governance has always been recognized to be a critical tool for advancing sustainable development and a crucial element to be 
incorporated in sustainable development strategies [15]. Especially in Asian developing countries, good governance is a key factor that can contribute significantly to their growth. As in the study of comparatively investigating level of governance of Thailand and few other Asian countries, good governance can additionally be a significant factor that contributes to growth of income per head [16]. The community enterprises producing renewable energy, therefore, should concern good governance as a principle for sustainable growth.

\subsection{Stakeholder theory}

According to stakeholder theory, the key objective of business is to create value for all stakeholders, any groups or individuals who can affect or is affected by the achievement of the firm's objectives, involved [17]. Stakeholder theory and sustainability management share a lot of ideas and thus stakeholder theory can be purposefully applied in the context of sustainability management [18]. In the empirical research, the first step in applying the concept of stakeholder theory for sustainability would be to acknowledge that using indicators which measure only financial success for only one group of stakeholders is insufficient. If financial indicators are used in empirical examinations of the stakeholder business case for sustainability concept, these should be accompanied by broader indicators on (environmental and social) value creation and should measure financial value creation in a way that is relevant not only for financiers but also for other stakeholders. For some kinds of value creation, it might even be most appropriate to use indicators that cannot be quantified at all. Acknowledging these challenges in measuring value creation for stakeholders will help bring business back to its roots from ancient times, that is, creating an exchange that produces value for all actors involved in the exchange [19]. Consequently, the sustainability indicators in this study assess all stakeholders of the community enterprises producing renewable energy in Thailand not only economic aspect, but also social and environmental aspects.

\section{CONCEPTUAL FRAMEWORK}

The Sustainability Balanced Scorecard (SBSC) has been applied as a key conceptual framework since it is a management and assessment tool focused on sustainable balance for economic, social and environmental aspects which are highly suitable and in line with the objectives of this study.

The sustainability indicators for Community Enterprises producing renewable energy in Thailand balance the three dimensions: (1) economic dimension (2) social dimension (3) environmental dimension. The three dimensions are linked together. The economic dimension consists of four perspectives: financial, stakeholder, internal process, and learning and growth which a slight adjustment of the perspective has been made to the traditional Balanced Scorecard (BSC) so that the sustainability indicators can be established more clearly in the context of community enterprises producing renewable energy in Thailand.

For developing each issue of sustainability indicators for community enterprises producing renewable energy in Thailand, the Sustainable Development Goals (SDGs), the Sufficiency Economy Philosophy (SEP), the characteristics of good governance, and the stakeholder theory have been applied.

The conceptual framework of the study, therefore, consists of six perspectives: (1) financial perspective (2) stakeholder perspective (3) internal process perspective (4) learning and growth perspective (5) social perspective (6) environmental perspective as shown in Figure 1

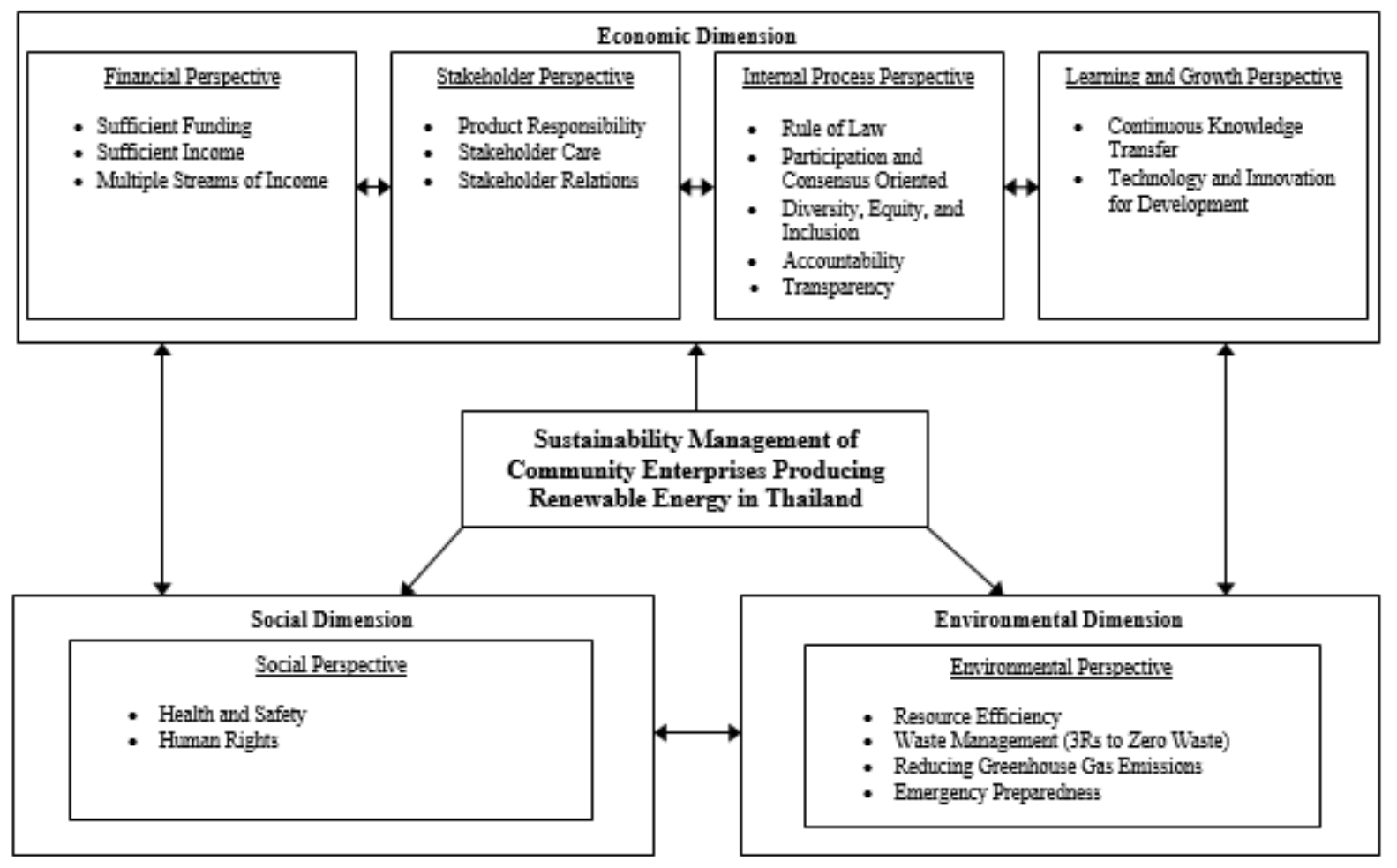

Figure 1. Conceptual framework of the study 


\section{METHODS}

The details of the study methods are as follows:

(1) Reviewing literature and surveying a community enterprise producing renewable energy in Thailand by using informal interviews and non-participating observation.

Secondary data was collected from academic papers, books, articles, research, and other information from reliable sources on various related issues such as policies and plans of renewable energy in Thailand, characteristics and situation of community enterprises in Thailand, as well as concepts and theories of sustainability management.

Primary data was collected from surveying a community enterprise producing renewable energy (biogas) where operates in accordance with sustainable development and the philosophy of sufficiency economy for many years receiving awards and being recognized as a model in renewable energy production.

(2) Developing sustainability indicators for community enterprises producing renewable energy in Thailand by synthesizing the data.

From the conceptual framework, deductive method was used. The secondary data and the primary data obtained from the literature review and the survey were synthesized to develop sustainability indicators for community enterprises producing renewable energy in Thailand.

(3) Assessing the sustainability indicators for community enterprises producing renewable energy in Thailand by experts and academics.

To make the sustainability indicators for community enterprises producing renewable energy in Thailand reliable, they were assessed by eighteen experts and academics (key informants). The assessment form and the semi-structured interview form are made using as tools, which are flexible and able to compare information from multiple key informants without missing the key issue in order to gain insights, a deep and correct understanding of the views, experiences, ideas, and attitudes of key informants.

For the principles of assessing each indicator, "Index of Item-Objective Congruence (IOC)", the principle of determination of the individual accuracy of the test by experts, has been applied to evaluate the indicators based on the score range from -1 to +1 , where the acceptable indicator must have an average score of more than 0.50. Inductive approach also was used to analyze, interpret, and conclude the data from interviewing the eighteen experts and academics.

\subsection{Key informants}

In this study, key informants were selected by using purposive sampling method to be consistent and cover the study objectives. The main objective of this study is to propose sustainability indicators for community enterprises producing renewable energy in Thailand. Therefore, it needs opinions from experts in energy management both in government organizations, state enterprises, and energy business organizations as well as academics in social and environmental development for sustainability.

The principle of selecting the number of key informants of the Delphi technique was applied for the number of key informants of this study as the Delphi technique is a technique that systematically utilizes the opinions of thematic experts. However, instead of using several rounds of questionnaires, the assessment form and the semi-structured interview form was used as tools in this study to achieve a consensus.

Thomas T. Macmillan studied and presented the results of the research on the number of experts in the Delphi technique that if there are seventeen or more experts, the error rate will be very low and will start to stabilize at a tolerance level of 0.02 [20]. Therefore, a total of eighteen key informants were selected in this study, and divided into three groups with equal member each.

(1) Six experts in energy management with at least a master's degree and working experience in energy for government organizations or state enterprises for a period of not less than three years.

(2) Six experts in energy management with at least a master's degree and working experience in the energy business organization for a period of not less than three years.

(3) Six academics on social and environmental development with at least a doctorate degree and experience in teaching or research in social and environmental development for a period of not less than three years.

\section{RESULTS AND DISCUSSION}

The sustainability indicators developed from the conceptual framework of this study which the Sustainable Development Goals (SDGs), the Sufficiency Economy Philosophy (SEP), the characteristics of good governance, and the stakeholder theory have been applied plus the data obtained from the literature review and the survey. Every sustainability indicator must also consider ethical issues and the philosophy of sufficiency economy regarding morality condition. The details of the nineteen sustainability indicators for community enterprises producing renewable energy in Thailand which could be divided into six perspectives are as follows:

\subsection{Financial perspective}

The philosophy of sufficiency economy regarding moderation, reasonableness and self-immunity principles has been applied to this perspective, which can be interpreted in three issues respectively:

\subsubsection{Sufficient funding}

Sufficient funding means that the community enterprise producing renewable energy is able to access to sources of capital and provide sufficient funds for their operations, which proposes one sustainability indicator:

(1) Number of the community enterprise producing renewable energy's sources of funds.

The criterion for assessment is the greater number of the community enterprise producing renewable energy's sources of funds, the better will be.

\subsubsection{Sufficient income}

Sufficient income means that the community enterprise producing renewable energy is able to generate more income than expenses, which proposes one sustainability indicator:

(2) The community enterprise producing renewable energy's ratio of income to expenditure.

The criterion for assessment is the greater number of the community enterprise producing renewable energy's ratio of income to expenditure, the better will be. 


\subsubsection{Multiple streams of income}

Multiple streams of income means that the community enterprise producing renewable energy is able to have several different sources of income, which proposes one sustainability indicator:

(3) Number of the community enterprise producing renewable energy's income sources.

The criterion for assessment is the greater number of the community enterprise producing renewable energy's sources of income, the better will be.

\subsection{Stakeholder perspective}

The stakeholder theory has been applied to this perspective, which can be interpreted in three issues:

\subsubsection{Product responsibility}

Product responsibility means that the community enterprise producing renewable energy is responsible for the entire lifecycle of the product, which proposes one sustainability indicator:

(4) Number of activities which the community enterprise producing renewable energy is responsible for the entire lifecycle of the product.

The criterion for assessment is the greater number of activities which the community enterprise producing renewable energy is responsible for the entire life-cycle of the product, the better will be.

\subsubsection{Stakeholder care}

Stakeholder care means the community enterprise producing renewable energy is able to satisfy the stakeholders. The community enterprise producing renewable energy should know the stakeholders' needs or expectations and operate in response to the needs or expectations, which proposes one sustainability indicator:

(5) Number of activities which the community enterprise producing renewable energy has done to satisfy the stakeholders.

The criterion for assessment is the greater number of activities which the community enterprise producing renewable energy has done to satisfy the stakeholders, the better will be.

\subsubsection{Stakeholder relations}

Stakeholder relations means that the community enterprise producing renewable energy is able to build good relationships with the stakeholders, which proposes one sustainability indicator:

(6) Number of activities which the community enterprise producing renewable energy has established good relationships with the stakeholders.

The criterion for assessment is the greater number of activities which the community enterprise producing renewable energy has established good relationships with the stakeholders, the better will be.

\subsection{Internal process perspective}

The characteristics of good governance have been applied to this perspective, which can be interpreted in five issues:

\subsubsection{Rule of law}

Rule of law means that the community enterprise producing renewable energy operates in accordance with rules, regulations, or any relevant laws, which proposes one sustainability indicator:

(7) Number of activities which the community enterprise producing renewable energy has operated in accordance with rules, regulations, or any relevant laws.

The criterion for assessment is the greater number of activities which the community enterprise producing renewable energy has operated in accordance with rules, regulations, or any relevant laws, the better will be.

\subsubsection{Participation and consensus oriented}

Participation and consensus oriented means that the community enterprise producing renewable energy provides opportunities for the stakeholders to participate in expressing opinions and decisions need to be made to mediate differing interests, which proposes one sustainability indicator:

(8) Number of activities which the community enterprise producing renewable energy has provided opportunities for the stakeholders to participate in expressing opinions and has made decisions to mediate differing interests.

The criterion for assessment is the greater number of activities which the community enterprise producing renewable energy has provided opportunities for the stakeholders to participate in expressing opinions and has made decisions to mediate differing interests, the better will be.

\subsubsection{Diversity, equity, and inclusion}

Diversity, equity, and inclusion means that the community enterprise producing renewable energy has equally operated without discrimination against a variety of gender, age, or physical disability of persons, ensuring that all the members feel included and empowered to improve or maintain their well-being, which proposes one sustainability indicator:

(9) Number of activities which the community enterprise producing renewable energy has equally operated without discrimination against a variety of gender, age, or physical disability of persons, ensuring that all the members feel included and empowered to improve or maintain their wellbeing.

The criterion for assessment is the greater number of activities which the community enterprise producing renewable energy has equally operated without discrimination against a variety of gender, age, or physical disability of persons, ensuring that all the members feel included and empowered to improve or maintain their well-being, the better will be.

\subsubsection{Accountability}

Accountability means that the community enterprise producing renewable energy is completely responsible for the operational-related results and has prepared to justify the actions, which proposes one sustainability indicator:

(10) Number of activities which the community enterprise producing renewable energy is completely responsible for the operational-related results and has prepared to justify the actions.

The criterion for assessment is the greater number of activities which the community enterprise producing renewable energy is completely responsible for the operational-related results and has prepared to justify the actions, the better will be. 


\subsubsection{Transparency}

Transparency means that the community enterprise producing renewable energy operates in a transparent manner, business information is accessible to the public, understandable, and monitorable, which proposes one sustainability indicator:

(11) Amount of the community enterprise producing renewable energy's business information which is accessible to the public, understandable, and monitorable.

The criterion for assessment is the greater amount of the community enterprise producing renewable energy's business information which is accessible to the public, understandable, and monitorable, the better will be.

\subsection{Learning and growth perspective}

The philosophy of sufficiency economy regarding knowledge condition has been applied to this perspective, which can be interpreted in two issues:

\subsubsection{Continuous knowledge transfer}

Continuous knowledge transfer means that the community enterprise producing renewable energy continuously transfer knowledge and skills necessary for the operations, which proposes one sustainability indicator:

(12) Number of activities which the community enterprise producing renewable energy has done to transfer knowledge and skills necessary for the operations.

The criterion for assessment is the greater number of activities which the community enterprise producing renewable energy has done to transfer knowledge and skills necessary for the operations, the better will be.

\subsubsection{Technology and innovation for development}

Technology and innovation for development means that the community enterprise producing renewable energy integrates knowledge, apply modern technologies and innovations to improve the operations, which proposes one sustainability indicator:

(13) Number of technologies and innovations that the community enterprise producing renewable energy has used for development.

The criterion for assessment is the greater number of technologies and innovations that the community enterprise producing renewable energy has used for development, the better will be.

\subsection{Social perspective}

The Sustainable Development Goals (SDGs) have been applied to this perspective, which can be interpreted in two issues:

\subsubsection{Health and safety}

Health and safety means that the community enterprise producing renewable energy operates with a focus on health and safety, which proposes one sustainability indicator:

(14) Number of illnesses, injuries, and deaths from the community enterprise producing renewable energy operations.

The criterion for assessment is the smaller number of illnesses, injuries, and deaths from the community enterprise producing renewable energy operations, the better will be.

\subsubsection{Human rights}

Human rights means that the community enterprise producing renewable energy integrates human rights principles into the operations, which proposes one sustainability indicator:

(15) Number of human rights violations from the community enterprise producing renewable energy operations.

The criterion for assessment is the smaller number of human rights violations from the community enterprise producing renewable energy operations, the better will be.

\subsection{Environmental perspective}

The Sustainable Development Goals (SDGs) have been applied to this perspective, which can be interpreted in four issues:

\subsubsection{Resource efficiency}

Resource efficiency means that the community enterprise producing renewable energy efficient uses of exhaustible natural resources, which proposes one sustainability indicator:

(16) Number of exhaustible natural resources in the community that the community enterprise producing renewable energy has used.

The criterion for assessment is the smaller number of exhaustible natural resources in the community that the community enterprise producing renewable energy has used, the better will be.

\subsubsection{Waste management (3Rs to Zero Waste)}

Waste management (3Rs to Zero Waste) means that the community enterprise producing renewable energy manages waste from its inception to its final disposal through the 3Rs, the principle of reducing waste, reusing and recycling resources and products, to achieve zero waste or near zero waste, which proposes one sustainability indicator:

(17) Amount of waste that the community enterprise producing renewable energy has generated.

The criterion for assessment is the smaller amount of waste that the community enterprise producing renewable energy has generated, the better will be.

\subsubsection{Reducing greenhouse gas emission}

Reducing greenhouse gas emission means that the community enterprise producing renewable energy reduces greenhouse gas emissions, which proposes one sustainability indicator:

(18) Number of activities which the community enterprise producing renewable energy has done to reduce greenhouse gas emission.

The criterion for assessment is the greater number of activities which the community enterprise producing renewable energy has done to reduce greenhouse gas emission, the better will be.

\subsubsection{Emergency preparedness}

Emergency preparedness means that the community enterprise producing renewable energy has prepared to deal with environmental problems that may arise in the community, which proposes one sustainability indicator:

(19) Number of emergency preparedness plans which the community enterprise producing renewable energy has prepared to deal with environmental problems that may arise in the community. 
Table 1. The assessment results

\begin{tabular}{|c|c|c|c|c|}
\hline Dimension & Perspective & Issue & Sustainability Indicator & $\begin{array}{c}\text { IOC } \\
\text { Score }\end{array}$ \\
\hline \multirow{13}{*}{ Economic } & \multirow{3}{*}{ Financial } & Sufficient Funding & (1) Number of the community enterprise's sources of funds & 0.722 \\
\hline & & Sufficient Income & (2) The community enterprise's ratio of income to expenditure & 0.667 \\
\hline & & $\begin{array}{l}\text { Multiple Streams of } \\
\text { Income }\end{array}$ & (3) Number of the community enterprise's income sources & 0.722 \\
\hline & \multirow{3}{*}{ Stakeholder } & $\begin{array}{c}\text { Product } \\
\text { Responsibility }\end{array}$ & $\begin{array}{l}\text { (4) Number of activities which the community enterprise is } \\
\text { responsible for the entire life-cycle of the product }\end{array}$ & 0.944 \\
\hline & & Stakeholder Care & $\begin{array}{l}\text { (5) Number of activities which the community enterprise has done to } \\
\text { satisfy the stakeholders }\end{array}$ & 0.889 \\
\hline & & $\begin{array}{l}\text { Stakeholder } \\
\text { Relations }\end{array}$ & $\begin{array}{l}\text { (6) Number of activities which the community enterprise has built } \\
\text { good relationships with the stakeholders }\end{array}$ & 0.778 \\
\hline & \multirow{5}{*}{ Internal Process } & Rule of Law & $\begin{array}{l}\text { (7) Number of activities which the community enterprise has } \\
\text { operated in accordance with rules, regulations, or any relevant laws }\end{array}$ & 0.833 \\
\hline & & $\begin{array}{l}\text { Participation and } \\
\text { Consensus Oriented }\end{array}$ & $\begin{array}{l}\text { (8) Number of activities which the community enterprise has } \\
\text { provided opportunities for the stakeholders to participate in } \\
\text { expressing opinions and has made decisions to mediate differing } \\
\text { interests }\end{array}$ & 0.944 \\
\hline & & $\begin{array}{l}\text { Diversity, Equity, } \\
\text { and Inclusion }\end{array}$ & $\begin{array}{l}\text { (9) Number of activities which the community enterprise has equally } \\
\text { operated without discrimination against a variety of gender, age, or } \\
\text { physical disability of persons, ensuring that all the members feel } \\
\text { included and empowered to improve or maintain their well-being }\end{array}$ & 0.889 \\
\hline & & Accountability & $\begin{array}{l}\text { (10) Number of activities which the community enterprise is } \\
\text { completely responsible for the operational-related results and has } \\
\text { prepared to justify the actions }\end{array}$ & 0.833 \\
\hline & & Transparency & $\begin{array}{l}\text { (11) Amount of the community enterprise's business information } \\
\text { which is accessible to the public, understandable, and monitorable }\end{array}$ & 1 \\
\hline & \multirow{2}{*}{$\begin{array}{l}\text { Learning and } \\
\text { Growth }\end{array}$} & $\begin{array}{c}\text { Continuous } \\
\text { Knowledge Transfer }\end{array}$ & $\begin{array}{l}\text { (12) Number of activities which the community enterprise has done } \\
\text { to transfer knowledge and skills necessary for the operations }\end{array}$ & 0.944 \\
\hline & & $\begin{array}{l}\text { Technology and } \\
\text { Innovation for } \\
\text { Development }\end{array}$ & $\begin{array}{l}\text { (13) Number of technologies and innovations that the community } \\
\text { enterprise has used for development }\end{array}$ & 0.944 \\
\hline \multirow{2}{*}{ Social } & \multirow{2}{*}{ Social } & Health and Safety & $\begin{array}{l}\text { (14) Number of illnesses, injuries, and deaths from the community } \\
\text { enterprise operations }\end{array}$ & 0.944 \\
\hline & & Human Rights & $\begin{array}{l}\text { (15) Number of human rights violations from the community } \\
\text { enterprise operations }\end{array}$ & 0.944 \\
\hline \multirow{4}{*}{ Environmental } & \multirow{4}{*}{ Environmental } & Resource Efficiency & $\begin{array}{l}\text { (16) Number of exhaustible natural resources in the community that } \\
\text { the community enterprise has used }\end{array}$ & 0.889 \\
\hline & & $\begin{array}{l}\text { Waste Management } \\
\text { (3Rs to Zero Waste) }\end{array}$ & (17) Amount of waste that the community enterprise has generated & 0.889 \\
\hline & & $\begin{array}{l}\text { Reducing } \\
\text { Greenhouse Gas } \\
\text { Emission }\end{array}$ & $\begin{array}{l}\text { (18) Number of activities which the community enterprise has done } \\
\text { to reduce greenhouse gas emission }\end{array}$ & 0.889 \\
\hline & & $\begin{array}{c}\text { Emergency } \\
\text { Preparedness }\end{array}$ & $\begin{array}{l}\text { (19) Number of emergency preparedness plans which the community } \\
\text { enterprise has prepared to deal with environmental problems that } \\
\text { may arise in the community }\end{array}$ & 0.944 \\
\hline
\end{tabular}

The criterion for assessment is the greater number of emergency preparedness plans which the community enterprise producing renewable energy has prepared to deal with environmental problems that may arise in the community, the better will be.

\subsection{The assessment results and discussion}

The assessment results from the eighteen experts and academics show that the sustainability indicators developed by the researcher are all acceptable with the IOC scores between $0.667-1$ as can be summarized in Table 1 .

Although all indicators are acceptable, interviewing the eighteen experts and academics helps the researcher deeply understand the key informants' opinions. The IOC score of the second indicator is the lowest due to the fact that the nature of the community enterprises producing renewable energy in Thailand is not for profit maximization, but for self-reliance. Nevertheless, It is reasonable that the operation of the community enterprises should not loss.

At the policy level, the issues of this sustainability indicators for community enterprises producing renewable energy in Thailand has been in line with the government policy. Thai government has adopted the principles from the national strategy and the vision of "Thailand 4.0" as a starter, combined with the Sufficiency Economy Philosophy (SEP) and the Sustainable Development Goals (SDGs), crystallized into the BCG economy model, the new economic model, to achieve economic growth, compete globally and distribute income into the community, reduce disparity, strengthen society, be environmentally friendly which in turn will lead to sustainable development. The BCG model helps develop three economies: (1) Bioeconomy, an economy that focuses on the efficient use of biological resources by bringing science, technology and innovation to add value to resources for the production of goods, services, and utilization according to biological principles [21] (2) Circular Economy, an economy that focuses on the reuse of resources at maximum as not to cause a 
shortage problem and create added value from the recycling of resources as well as processes to reduce waste or reduce waste to zero [22] and (3) Green Economy, an economy that focuses on environmental sustainability, appropriate uses of resources with cost effectiveness, even redistribution of wealth, greenhouse gases reduction, the quality of living improvement, and reduction of environmental risks [23]. The issues of the sustainability indicators in this study conform to the BCG model. For example, the issue "Technology and Innovation for Development" is consistent with the Bioeconomy. the issue of "Resource Efficiency" and "Waste Management (3Rs to Zero Waste)" are in line with the Circular Economy. The issue of "Reducing Greenhouse Gas Emission" is consistent with the Green Economy.

\section{CONCLUSIONS AND RECOMMENDATION}

From the results above, there are nineteen indicators of sustainability indicators for community enterprises producing renewable energy in Thailand, which are divided into six perspectives: (1) financial perspective of three indicators (2) stakeholder perspectives of three indicators (3) internal process perspective of five indicators (4) learning and growth perspective of two indicators (5) social perspective of two indicators (6) environmental perspective of four indicators. The community enterprises producing renewable energy in Thailand, the government sector or related agencies can use these sustainability indicators as a tool to assess the sustainability of community enterprises producing renewable energy in Thailand.

However, this study should be furthered by researching other community enterprises producing other kinds of renewable energy besides biogas and developing a model or operating guidelines for community enterprises producing renewable energy in Thailand for self-reliance. The government sector or related agencies can use this to further formulate appropriate policies or measures to support the community enterprises producing renewable energy in Thailand to achieve sustainable success. When such community enterprises can be self-reliance and sustainable, it will result in a strong growth of the grassroots economy, greater energy security, reduction of negative impacts on society and the environment from non-renewable energy consumption. It is considered economic development along with social development and environmental conservation in a balanced and sustainable manner which will be a solid and sustainable foundation for Thailand.

\section{REFERENCES}

[1] Energy Policy and Planning Office. Problems and Impacts of Energy Use. http://www.ereport.energy.go.th/EPPO_files/media-03.pdf.

[2] Barragán, A., Terrados, J. (2017). Sustainable cities: An analysis of the contribution made by renewable energy under the umbrella of urban metabolism. International Journal of Sustainable Development and Planning, 12(3): 416-424. https://doi.org/10.2495/SDP-V12-N3-416-424

[3] LEP Center. Local Energy Planning project. http://ppp.energy.go.th/wpcontent/uploads/2017/03/\%E0\%B8\%84\%E0\%B8\%A7 $\%$ Е0\%В8\%В2\%Е0\%В8\%A1\%Е0\%В9\%80\%Е0\%В8\%
9B\%Е0\%B9\%87\%Е0\%B8\%99\%Е0\%B8\%A1\%Е0\%B 8\%B2\%E0\%B8\%82\%E0\%B8\%AD\%E0\%B8\%87LEP. pdf.

[4] Somswasdi, C., Thongsukhowon, A., Nakapaksin, S. (2015). The guidelines for management of community enterprises: A case study of Don Chang sub-district, Khon Kaen Province, Thailand. Asian Social Science, 11(5). https://doi.org/10.5539/ass.v11n5p91

[5] Kaplan, R.S., Norton, D.P. (1992). The balanced scorecard - measures that drive performance. Harvard Business Review. https://hbr.org/1992/01/the-balancedscorecard-measures-that-drive-performance-2.

[6] Figge, F., Hahn, T., Schaltegger, S., Wagner, M. (2002). The Sustainability Balanced Scorecard - Linking sustainability management to business strategy. Business Strategy and the Environment, 11(5): 269-284. https://doi.org/10.1002/bse.339

[7] Boerrigter, S. (2015). The use of the Sustainability Balanced Scorecard Framework for Dutch SMEs as a tool for measuring the performance of their sustainability strategy.

[8] Abdelrazek, A.F. (2019). Sustainability balanced scorecard: A comprehensive tool to measure sustainability performance. International Journal of Social Science and Economic Research, 4: 948-962.

[9] United Nations. Take Action for the Sustainable Development

Goals. https://www.un.org/sustainabledevelopment/sustainable -development-goals/.

[10] United Nations Global Compact. The Ten Principles of the UN Global Compact. https://www.unglobalcompact.org/what-is$\mathrm{gc} / \mathrm{mission} /$ principles.

[11] Littlewood, D., Holt, D. (2018). How social enterprises can contribute to the sustainable development goals (SDGs) - A conceptual framework. In Entrepreneurship and the Sustainable Development Goals. https://doi.org/10.1108/S2040-724620180000008007

[12] Mongsawad, P. (2010). The philosophy of the sufficiency economy: A contribution to the theory of development. Asia-Pacific Development Journal, 17(1): 123-143. http://doi.org/10.18356/02bd5fb3-en

[13] Khunthongjan, S., Wiboonpongse, A. (2010). A study of performance of SMEs in their application of sufficiency economy philosophy. GMSARN International Journal, 4 177-182.

[14] UNESCAP. What is Good Governance? https://www.unescap.org/sites/default/files/goodgovernance.pdf

[15] Kardos, M. (2012). The reflection of good governance in sustainable development strategies. Procedia - Social and Behavioral Sciences, 58: 1166-1173. https://doi.org/10.1016/j.sbspro.2012.09.1098

[16] Kraipornsak, P. (2018). Good governance and economic growth: an investigation of Thailand and selected Asian countries. Eurasian Journal of Economics and Finance, 6(1): 93-106. https://doi.org/10.15604/ejef.2018.06.01.009

[17] Freeman, R.E. (2010). Strategic Management: A Stakeholder Approach. Cambridge: Cambridge University Press. https://doi.org/10.1017/CBO9781139192675

[18] Hörisch, J., Freeman, R.E., Schaltegger, S. (2014). Applying stakeholder theory in sustainability 
management. Organization \& Environment, 27(4): 328346. https://doi.org/10.1177/1086026614535786

[19] Schaltegger, S., Hörisch, J., Freeman, R.E. (2019). Business cases for sustainability: A stakeholder theory perspective. Organization \& Environment, 32(3): 191212. https://doi.org/10.1177/1086026617722882

[20] Macmillan, T.T. (1971). The Delphi Technique. Paper presented at the Paper presented at the annual meeting of the California Junior Colleges Associations Committee on Research and Development, Monterey, California.

[21] National Science and Technology Development Agency
(NSTDA).

(2019).

Bioeconomy.

https://waa.inter.nstda.or.th/stks/pub/2019/20190318book-bioeconomy.pdf.

[22] Thailand Institute of Scientific and Technological Research. (2019). Circular Economy. https://www.mhesi.go.th/images/STBookSeries/BS003 CircularEconomy.pdf.

[23] National Science and Technology Development Agency (NSTDA). (2019). Green Economy. https://waa.inter.nstda.or.th/stks/pub/2019/20190318book-green-economy.pdf. 